\title{
Bratislava 2000
}

\author{
By Ron Holloway
}

Spring 2001 Issue of KINEMA

\section{2nd BRATISLAVA INTERNATIONAL FILM FESTIVAL 2000}

For, beyond the shadow of a doubt, the $2^{\text {nd }}$ Bratislava International Film Festival (1-9 December 2000), under Vladimir Krajniak (director) and Peter Nagel (programmer), is one of the most exciting on the European scene. With 123 films programmed in eight sections at six venues (89 more than in 1999), with a strong international competition of 19 feature films, with a showcase spotlighting "V4" countries (namely, the "Visegrad Four": Poland, Hungary, Slovakia, and the Czech Republic), with retrospective tributes to Mika Kaurismäki and Philippine Cinema, with Italy's Stefania Sandrelli and South Africa's Ian Kerkhof among the guests, with a 205-page catalogue and a festival daily, BIFF 2000 easily doubled last year's attendance midway through the festival and wrapped comfortably with over 40,000 visitors.

For that matter, Slovak cinema is on the rebound too. Following the downfall in 1998 of nationalist prime minster Vladimír Mečiar, whose disastrous four-year rule had brought the country to the brink of economic ruin, Slovakia under newly elected prime minster Mikuláš Dzurinda is recasting its political profile in hopes of joining the European Community within five years. Consequently, the country's cultural and film image is on the upswing. True, the privatized Koliba Studios in Bratislava are still in the hands of the Mečiar siblings, but the decaying complex is not really needed for the modest slate of maximum three feature films produced annually over the past two years.

What counts is the attested quality of these productions. Martin Šulík's Landscape, a Slovak-Czech coproduction invited to Toronto and the Panorama at the Berlinale, impresses as a droll, humanistic, episodic chronicle of Slovak village life over the past century, scripted together with noted novelist-screenwriter Dušan Dušek. Dušan Hanák's feature documentary Intolerance -- Police State, currently in postproduction, is reckoned by knowledgeable critics as a powerful indictment of communist crimes. And Vlado Balco's Rain Is Falling on Our Souls follows on the heels of his lauded Rivers of Babylon (1998), a latter a powerful indictment of ex-prime minister Vladimir Mečiar couched in easy-to-interpret polemical metaphors.

To be sure, Slovakia's vital lifeline to European cinema for potential co-production support is the rejuvenated BIFF, with an energetic staff and distinct penchant for independent cinema the world over. Even its "Premieres" section focussed on innovative cinema seen on the festival circuit: Kenneth Branagh's opening night Love's Labour Lost (Berlin), Mary Harron's American Psycho (Berlin), Wim Wenders's The Million Dollar Hotel (Berlin), Jim Jarmusch's Ghost Dog (Cannes), Liv Ullmann's Unfaithful (Cannes), E. Elias Merhige's closing night Shadow of the Vampire (Cannes), Jan Švankmajer's Otesánek (Greedyguts, Venice), and Krzysztof Zanussi's Life as a Fatally Transmitted Sexual Disease (Moscow).

As for the competition, a dozen entries were deemed worthy of the $\$ 15,000$ purse prizes awarded by the International Jury. The Grand Prize went to Lynne Ramsay's Ratcatcher (UK) -- "for its creative vision, emotional tenderness, and intuitive evocation of a harsh childhood" -- together with the Best Actress award to Mandy Matthews. The Special Prize for Best Director was awarded to Lee Chang-dong's Bakha satang (Peppermint Candy, South Korea) -- "for its convincing and moving depiction of 20 years of recent South Korean history through the life of an individual" -- together with the Best Actor award to Sol Kyung-Gu.

Films singled out for special mentions were Hassan Yekpatanah's Djomeh (Iran), Vinko Bresan's Marshall Tito's Spirit (Croatia), and Lukas Moodysson's Tillsammans (Together, Sweden). Together also received the Audience Prize and the Slovak Film Theatres Award.

Boosted by a dozen private sponsors to supplement the running budget of circa $\$ 500,000$, and with the fortunate opening of a state-of-the-art multiplex in the Polus City Centre to augment the five venues in the spacious Istropolis, the Bratislava International Film Festival is well on its way to becoming a key European film festival. "Next year we hope to have a FIPRESCI (International Critics) Jury and an Ecumenical Jury on hand," confirmed the Krajniak-Nagel team. Considering that BIFF benefits from the close proximity of the Viennese airport (a 40-minute drive), they might well be flooded by international guests in 2001. 
Is this the missing piece in the puzzle? "We have no system for film financing," says Martin Šmatlák, head of the Slovak Film Institute and rumoured to become the new film minister under the present coalition government. "Moreover, we need to establish a film fund by law," he added. "Unfortunately, the old film law -- almost useless -- still exists."

\section{Author Information}

Ron HOLLOWAY (1933-2009) was an American critic, film historian, filmmaker and correspondent who adopted Europe as his home in the early fifties and spent much of his life in Berlin. He was an expert on the study of German cinema and against all odds produced, with his wife Dorothea, the journal German Film, keeping us up-to-date with the work of directors, producers and writers and the showing of German films around the world.

In 2007, Ron Holloway and his wife were awarded the Berlinale Camera Award. Ron also received the Bundesverdienstkreuz (German Cross of Merit), Polish Rings, Cannes Gold Medaille, the American Cinema Foundation Award, the Diploma for Support of Russian Cinema and an honorary award from the German Film Critics' Association.

Ron was also a valued contributor to Kinema for the past fifteen years. 